\title{
LEVEL II SCOUR ANALYSIS FOR BRIDGE 3 (BRIDTH00010003) on TOWN HIGHWAY 1, crossing DAILEY HOLLOW BRANCH, BRIDGEWATER, VERMONT
}

U.S. Geological Survey Open-File Report 96-237

Prepared in cooperation with

VERMONT AGENCY OF TRANSPORTATION and

FEDERAL HIGHWAY ADMINISTRATION 


\section{LEVEL II SCOUR ANALYSIS FOR BRIDGE 3 (BRIDTH00010003) on TOWN HIGHWAY 1, crossing DAILEY HOLLOW BRANCH, BRIDGEWATER, VERMONT}

By SCOTT A. OLSON and DONALD L. SONG

U.S. Geological Survey Open-File Report 96-237

Prepared in cooperation with

VERMONT AGENCY OF TRANSPORTATION and

FEDERAL HIGHWAY ADMINISTRATION 


\title{
U.S. DEPARTMENT OF THE INTERIOR BRUCE BABBITT, Secretary
}

\author{
U.S. GEOLOGICAL SURVEY \\ Gordon P. Eaton, Director
}

For additional information write to:

District Chief

U.S. Geological Survey 361 Commerce Way

Pembroke, NH 03275
Copies of this report may be purchased from:

U.S. Geological Survey Earth Science Information Center Open-File Reports Section Box 25286, MS 517 Federal Center

Denver, CO 80225 


\section{CONTENTS}

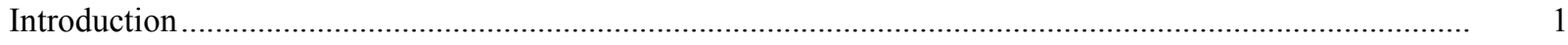

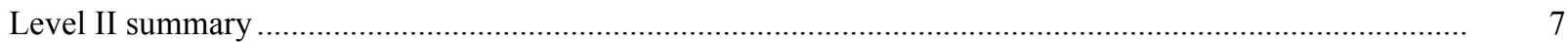

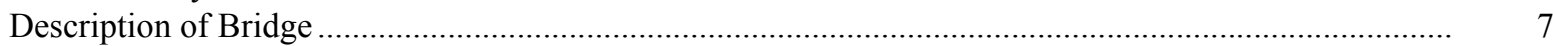

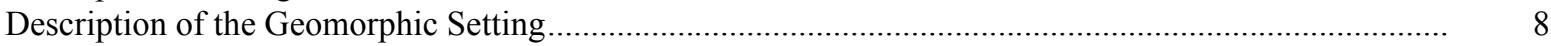

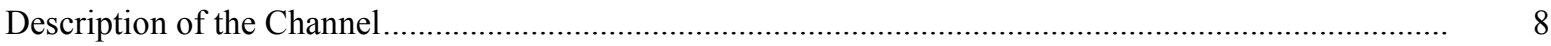

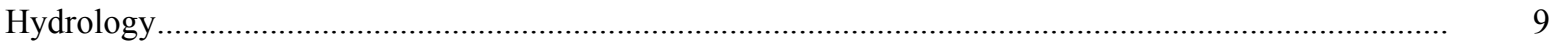

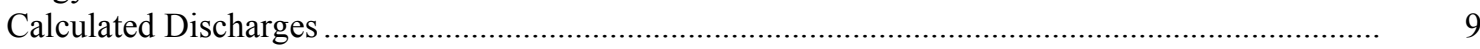

Description of the Water-Surface Profile Model (WSPRO) Analysis ......................................................... 10

Cross-Sections Used in WSPRO Analysis ......................................................................................

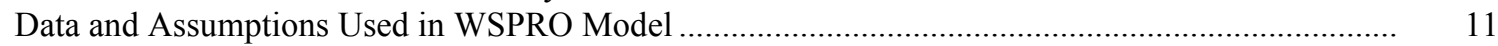

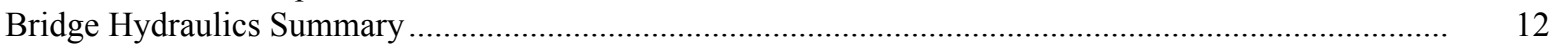

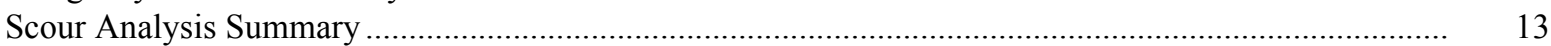

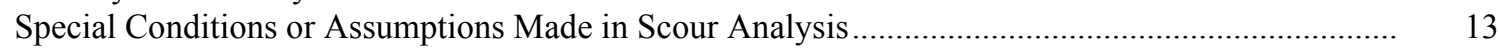

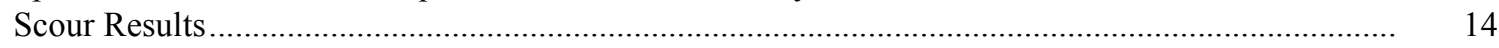

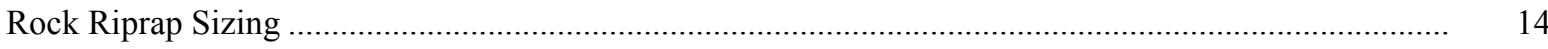

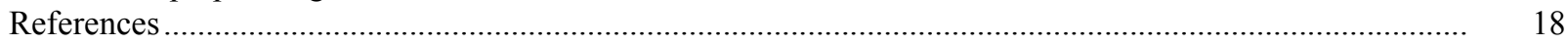

Appendixes:

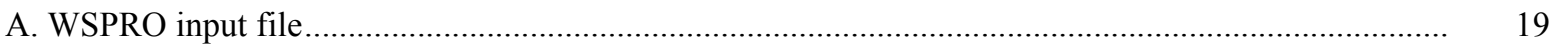

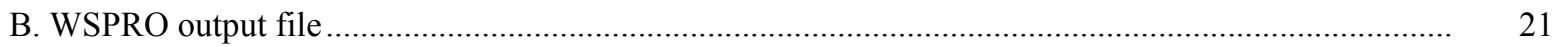

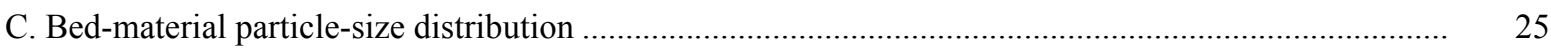

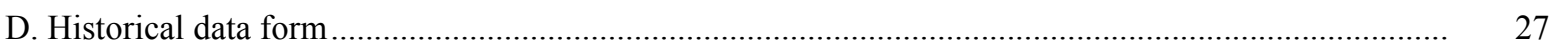

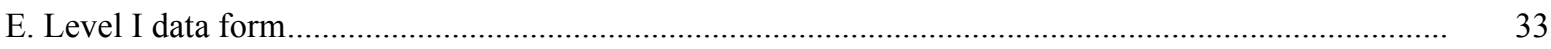

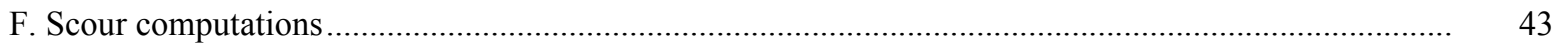

\section{FIGURES}

1. Map showing location of study area on USGS $1: 24,000$ scale map .......................................................

2. Map showing location of study area on Vermont Agency of Transportation town
highway map

3. Structure BRIDTH00010003 viewed from upstream (October 27, 1994)....................................................

4. Downstream channel viewed from structure BRIDTH00010003 (October 27, 1994),.............................. 5

5. Upstream channel viewed from structure BRIDTH00010003 (October 27, 1994)...................................... 6

6. Structure BRIDTH00010003 viewed from downstream (October 27, 1994) …............................................ 6

7. Water-surface profiles for the 100- and 500-year discharges at structure

BRIDTH00010003 on Town Highway 1, crossing Dailey Hollow Branch,

Bridgewater, Vermont.

8. Scour elevations for the 100- and 500-year discharges at structure

BRIDTH00010003 on Town Highway 1, crossing Dailey Hollow Branch,

Bridgewater, Vermont.

\section{TABLES}

1. Remaining footing/pile depth at abutments for the 100-year discharge at structure BRIDTH00010003 on Town Highway 1, crossing Dailey Hollow Branch,

Bridgewater, Vermont

2. Remaining footing/pile depth at abutments for the 500-year discharge at structure

BRIDTH00010003 on Town Highway 1, crossing Dailey Hollow Branch,

Bridgewater, Vermont.

\section{6}

5

6




\begin{tabular}{|c|c|c|}
\hline Multiply & By & To obtain \\
\hline \multicolumn{3}{|c|}{ Length } \\
\hline inch (in.) & 25.4 & millimeter (mm) \\
\hline foot $(\mathrm{ft})$ & 0.3048 & $\operatorname{meter}(\mathrm{m})$ \\
\hline mile (mi) & 1.609 & kilometer (km) \\
\hline \multicolumn{3}{|c|}{ Slope } \\
\hline foot per mile ( $\mathrm{ft} / \mathrm{mi})$ & 0.1894 & meter per kilometer $(\mathrm{m} / \mathrm{km})$ \\
\hline \multicolumn{3}{|c|}{ Area } \\
\hline square mile $\left(\mathrm{mi}^{2}\right)$ & 2.590 & square kilometer $\left(\mathrm{km}^{2}\right)$ \\
\hline \multicolumn{3}{|c|}{ Volume } \\
\hline cubic foot $\left(\mathrm{ft}^{3}\right)$ & $\begin{array}{l}0.02832 \\
\text { Velocity and Flow }\end{array}$ & cubic meter $\left(\mathrm{m}^{3}\right)$ \\
\hline foot per second $(\mathrm{ft} / \mathrm{s})$ & 0.3048 & meter per second $(\mathrm{m} / \mathrm{s})$ \\
\hline cubic foot per second $\left(\mathrm{ft}^{3} / \mathrm{s}\right)$ & 0.02832 & cubic meter per second $\left(\mathrm{m}^{3} / \mathrm{s}\right)$ \\
\hline $\begin{array}{l}\text { cubic foot per second per } \\
\text { square mile } \\
{\left[\left(\mathrm{ft}^{3} / \mathrm{s}\right) / \mathrm{mi}^{2}\right]}\end{array}$ & 0.01093 & $\begin{array}{l}\text { cubic meter per } \\
\text { second per square } \\
\text { kilometer }\left[\left(\mathrm{m}^{3} / \mathrm{s}\right) / \mathrm{km}^{2}\right]\end{array}$ \\
\hline
\end{tabular}

OTHER ABBREVIATIONS

$\begin{array}{lrlr}\mathrm{BF} & \text { bank full } & \text { LWW } & \text { left wingwall } \\ \mathrm{cfs} & \text { cubic feet per second } & \text { MC } & \text { main channel } \\ \mathrm{D}_{50} & \text { median diameter of bed material } & \text { RAB } & \text { right abutment } \\ \mathrm{DS} & \text { downstream } & \text { RABUT } & \text { face of right abutment } \\ \mathrm{elev} & \text { elevation } & \text { RB } & \text { right bank } \\ \mathrm{f} / \mathrm{p} & \text { flood plain } & \text { ROB } & \text { right overbank } \\ \mathrm{ft} & \text { square feet } & \text { RWW } & \text { right wingwall } \\ \mathrm{ft} / \mathrm{ft} & \text { feet per foot } & \text { TH } & \text { town highway } \\ \mathrm{JCT} & \text { junction } & \text { UB } & \text { under bridge } \\ \mathrm{LAB} & \text { left abutment } & \text { US } & \text { upstream } \\ \mathrm{LABUT} & \text { face of left abutment } & \text { USGS } & \text { United States Geological Survey } \\ \text { LB } & \text { left bank } & \text { VTAOT Vermont Agency of Transportation } \\ \text { LOB } & \text { left overbank } & \text { WSPRO } & \text { water-surface profile model }\end{array}$

In this report, the words "right" and "left" refer to directions that would be reported by an observer facing downstream. Sea level: In this report, "sea level" refers to the National Geodetic Vertical Datum of 1929-- a geodetic datum derived from a general adjustment of the first-order level nets of the United States and Canada, formerly called Sea Level Datum of 1929.

In the appendices, the above abbreviations may be combined. For example, USLB would represent upstream left bank. 


\title{
LEVEL II SCOUR ANALYSIS FOR BRIDGE 3 (BRIDTH00010003) ON TOWN HIGHWAY 1, CROSSING DAILEY HOLLOW BRANCH, BRIDGEWATER, VERMONT
}

\author{
By Scott A. Olson and Donald L. Song
}

\section{INTRODUCTION}

This report provides the results of a detailed Level II analysis of scour potential at structure BRIDTH00010003 on town highway 1 crossing Dailey Hollow Branch, Bridgewater, Vermont (figures 1-8). A Level II study is a basic engineering analysis of the site, including a quantitative analysis of stream stability and scour (U.S. Department of Transportation, 1993). A Level I study is included in Appendix E of this report. A Level I study provides a qualitative geomorphic characterization of the study site. Information on the bridge available from VTAOT files was compiled prior to conducting Level I and Level II analyses and can be found in Appendix D.

The site is in the Green Mountain physiographic division of central Vermont in the town of Bridgewater. The $9.88-\mathrm{mi}^{2}$ drainage area is in a predominantly rural, forested basin. In the vicinity of the study site, the immediate channel banks have moderate tree cover and shrubs with residential properties on the overbank.

In the study area, Dailey Hollow Branch has an incised, sinuous channel with a slope of approximately $0.009 \mathrm{ft} / \mathrm{ft}$, an average channel top width of $46 \mathrm{ft}$ and an average channel depth of $4 \mathrm{ft}$. The predominant channel bed materials are gravel and cobble with a median grain size $\left(\mathrm{D}_{50}\right)$ of $89.7 \mathrm{~mm}(0.294 \mathrm{ft})$. The geomorphic assessment at the time of the Level I and Level II site visit on October 27, 1994, indicated that the reach was vertically degrading.

The town highway 1 crossing of Dailey Hollow Branch is a 45 -ft-long, two-lane bridge consisting of one 42-foot steel-beam span (Vermont Agency of Transportation, written communication, August 24, 1994). The bridge is supported by vertical, concrete abutments with wingwalls. Type- 2 stone fill (less than 36 inches diameter) protects the downstream right and left wingwall. Type-3 stone fill (less than 48 inches diameter) exists on the downstream right bank. The left abutment is undermined by up to one foot. Horizontal probing under the abutment resulted in penetration up to 6 feet. 
The bridge is misaligned with the channel. Higher discharges may directly impact the left wingwall. The channel is skewed approximately 20 degrees to the bridge; the openingskew-to-roadway is also 20 degrees. Additional details describing conditions at the site are included in the Level II Summary and Appendices D

and $\mathrm{E}$.

Scour depths and rock rip-rap sizes were computed using the general guidelines described in Hydraulic Engineering Circular 18 (Richardson and others, 1993).

Total scour at a highway crossing is comprised of three components: 1) long-term aggradation or degradation; 2) contraction scour (due to reduction in flow area caused by a bridge) and; 3) local scour (caused by accelerated flow around piers and abutments). Total scour is the sum of the three components. Equations are available to compute scour depths for contraction and local scour and a summary of the results follows.

Contraction scour for all modelled flows ranged from $0.6 \mathrm{ft}$ to $1.3 \mathrm{ft}$ and the worst-case contraction scour occurred at the 500-year discharge. Abutment scour ranged from $6.7 \mathrm{ft}$ to $12.2 \mathrm{ft}$ and the worst-case abutment scour occurred at the 500-year discharge. Scour depths and depths to armoring are summarized on p. 14 in the section titled "Scour Results". Scour elevations, based on the calculated depths are presented in tables 1 and 2; a graph of the scour elevations is presented in figure 8 Scour depths were calculated assuming an infinite depth of erosive material and a homogeneous particle-size distribution.

For all scour presented in this report, "the scour depths adopted [by VTAOT] may differ from the equation values based on engineering judgement" (Richardson and others, 1993, p. 21, 27). It is generally accepted that the Froehlich equation (abutment scour) gives "excessively conservative estimates of scour depths" (Richardson and others, 1993, p. 48). Many factors, including historical performance during flood events, the geomorphic assessment, and the results of the hydraulic analyses, must be considered to properly assess the validity of abutment scour results. 


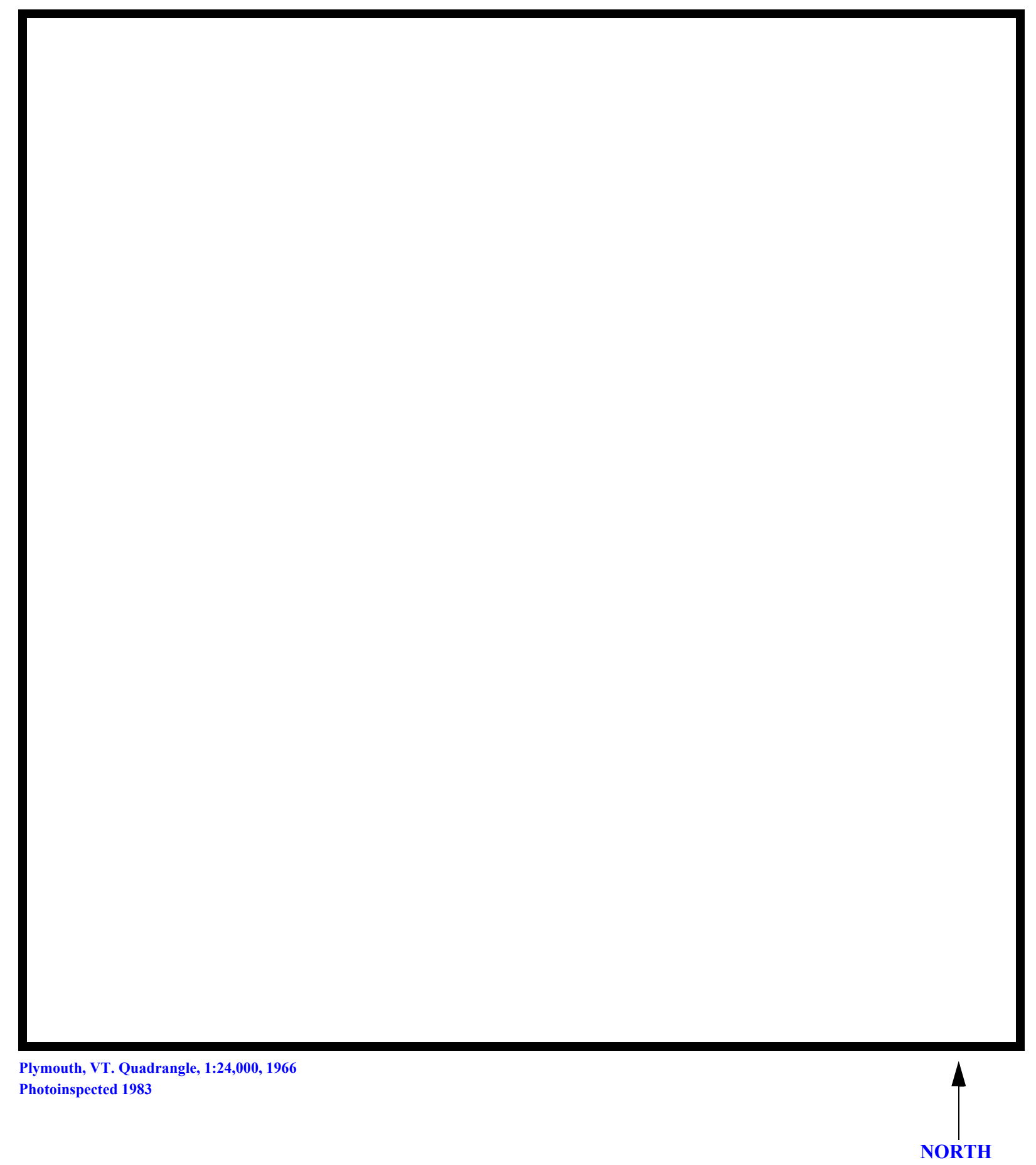

Figure 1. Location of study area on USGS 1:24,000 scale map. 
Figure 2. Location of study area on Vermont Agency of Transportation town highway map. 

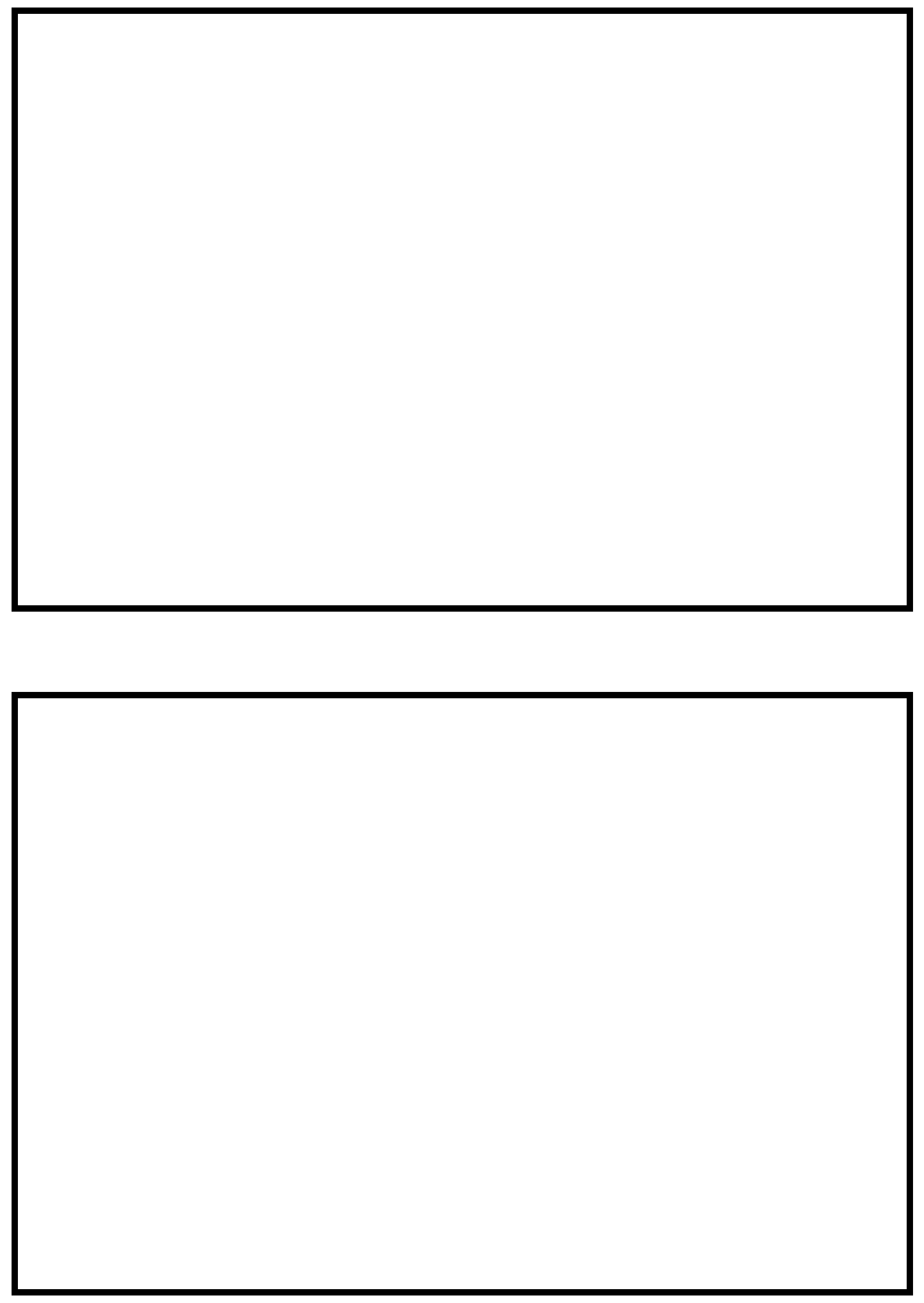

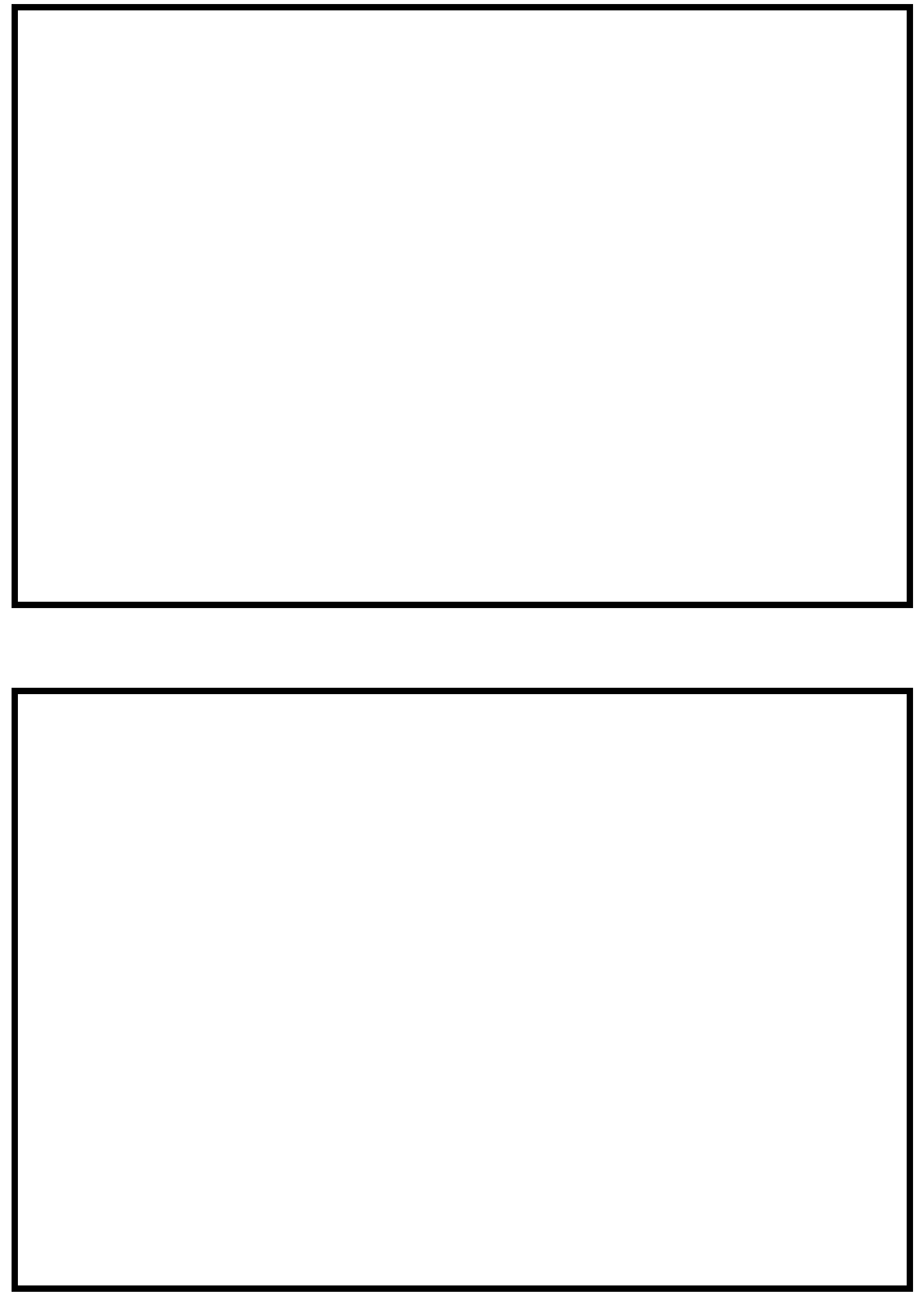


\section{LEVEL II SUMMARY}

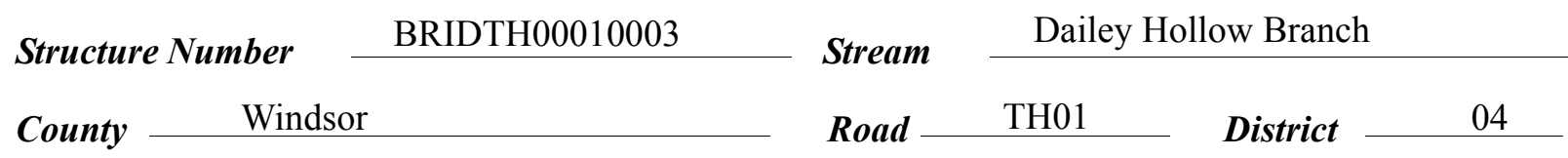

\section{Description of Bridge}

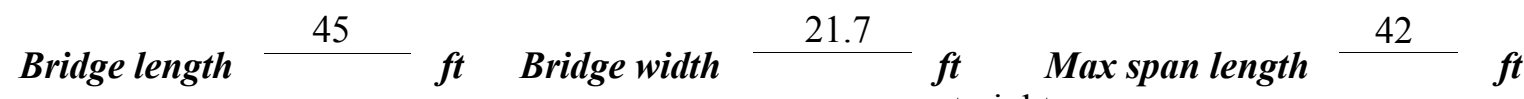
Alignment of bridge to road (on curve or straight)

\section{Abutment type} vertical and concrete

Stone fill on abutment?

$$
\text { No }
$$

\section{Embankment type} straight

$$
\text { sloping on right }
$$

Abutments and wingwalls are concrete. The left

abutment is undermined by a maximum measurement of one foot. Maximum horizontal penetration under the abutment is six feet.

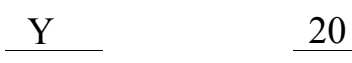

Angle

\begin{tabular}{|c|c|c|c|}
\hline & $\begin{array}{c}\text { Date of insnortion } \\
10 / 27 / 94 \\
\end{array}$ & $\begin{array}{l}\text { Percent of olmmmol } \\
\text { blocked inortzontatly }\end{array}$ & $\begin{array}{l}\text { Percent of } \\
\text { blocked verticatty }\end{array}$ \\
\hline & $10 / 27 / 94$ & 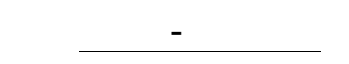 & - \\
\hline & Low & & \\
\hline
\end{tabular}

Debris accumulation on bridge at time of Level I or Level II site visit:

\section{Potential for debris}

The stream joins the North Branch of the Ottauquechee 185 feet downstream of the bridge. The Doscriho anv foaturos noar ar at tho hridoo that mav, affort flou, (includo ahsorvation dato) bridge is misaligned with the channel $(10 / 27 / 95)$. 


\section{Description of the Geomorphic Setting}

General topography The bridge crosses a high gradient incised upland stream with terraces in a moderate relief valley.

Geomorphic conditions at bridge site: downstream (DS), upstream (US)

Date of inspection $\quad 10 / 27 / 94$

DS left: $\quad$ Narrow flood plain to high terrace.

DS right: High terrace.

US left: $\quad$ High narrow terrace to valley wall.

US right: High narrow terrace to valley wall.

\section{Description of the Channel}

\begin{tabular}{|c|c|c|c|c|c|}
\hline & 46 & & & & 4 \\
\hline Average top width & & grave & it/cobble/boulder & ¿verage depth & gravel/cobble \\
\hline Predominant bed material & & & & Bank material & Straight, incised \\
\hline stream. & $v$ & $\cdot$ & $\cdots$ & .• & \\
\hline
\end{tabular}

$10 / 27 / 94$

Vegetative co ${ }^{1}$ Immediate bank is densely forested with lawn on overbank.

DS left: $\quad$ Minor woody vegetation on immediate bank; parking lot on overbank.

DS right: $\quad$ Forested; gravel roadway on narrow terrace.

US left: $\quad$ Forested; gravel roadway on narrow terrace.

US right:

$\mathrm{N}$

Do banks appear stable? October 27, 1994 , There is a cut bank on the downstream left and the dapstream right. All banks appear to be oversteepened.

October 27, 1994 None.

Describe any obstructions in channel and date of observation. 


\section{Hydrology}

Drainage area $\stackrel{9.88}{\mathrm{mi}^{2}}$

Percentage of drainage area in physiographic provinces: (approximate)

Physiographic province Green Mountain
Percent of drainage area 100

Is drainage area considered rural or urban?

Rural None.

urbanization:

Is there a USGS gage on the stream of interest?

No

\section{USGS gage description}

USGS gage number

Gage drainage area

$m i^{2}$

No

Is there a lake/p

. ... . .

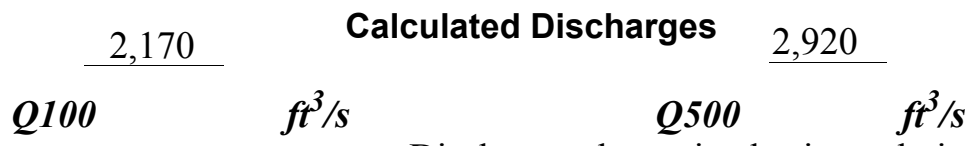

Discharges determined using a drainage area

relationship_with upstream_Bridgewater bridge 43 [(9.88/9.80) to the 0.7 power]. The Q100 and Q500 discharges at bridge 43 are 2,150 and 2,900 cubic feet per second, respectively. The Q100 at bridge 43 is from the VTAOT database (VTAOT, written communication, May, 1995); the Q500 is based on a weighted average of extrapolated discharges from applicable empirical methods (Talbot, 1887; Potter, 1957a \& b; Johnson and Laraway, 1971, written commun.; Johnson and Tasker, 1974; Federal Highway Administration, 1983). Bridge 43 has a drainage area of 9.8 square miles. 


\section{Description of the Water-Surface Profile Model (WSPRO) Analysis}

Datum for WSPRO analysis (USGS survey, sea level, VTAOT plans)

USGS survey

Datum tie between USGS survey and VTAOT plans $\quad$ Not applicable.

Description of reference marks used to determine USGS datum. $\quad$ RM1 is a chiseled X on

top of the downstream end of the right abutment (elev. $101.07 \mathrm{ft}$, arbitrary datum). RM2 is a

chiseled X on top of the upstream end of the left abutment (elev. $100.94 \mathrm{ft}$, arbitrary datum).

Cross-Sections Used in WSPRO Analysis

\begin{tabular}{cccl}
\hline${ }^{1}$ Cross-section & $\begin{array}{c}\text { Section } \\
\text { Reference } \\
\text { Distance } \\
\text { (SRD) } \text { in feet }\end{array}$ & $\begin{array}{c}{ }^{2} \text { Cross-section } \\
\text { development }\end{array}$ & \multicolumn{1}{c}{ Comments } \\
\hline EXITX & -73 & 1 & Exit section \\
FULLV & 0 & 2 & $\begin{array}{l}\text { Downstream Full-valley } \\
\text { section (Templated from } \\
\text { EXITX) }\end{array}$ \\
BRIDG & 0 & 1 & $\begin{array}{l}\text { Bridge section } \\
\text { Road Grade section }\end{array}$ \\
RDWAY & 11 & 1 & $\begin{array}{l}\text { Modeled Approach sec- } \\
\text { tion (Templated from } \\
\text { APPRO }\end{array}$ \\
& 62 & 2 & $\begin{array}{l}\text { SURV) } \\
\text { Approach section as sur- } \\
\text { veyed (Used as a tem- } \\
\text { plate) }\end{array}$ \\
\hline
\end{tabular}

${ }^{1}$ For location of cross-sections see plan-view sketch included with Level I field form, Appendix E.

For more detail on how cross-sections were developed see WSPRO input file. 


\section{Data and Assumptions Used in WSPRO Model}

Hydraulic analyses of the reach were done by use of the Federal Highway Administration's WSPRO step-backwater computer program (Shearman and others, 1986, and Shearman, 1990). The analysis reported herein reflects conditions existing at the site at the time of the study. Furthermore, in the development of the model it was necessary to assume no accumulation of debris or ice at the site. Results of the hydraulic model are presented in the Bridge Hydraulic Summary, Appendix B, and figure 7.

Channel roughness factors (Manning's " $n$ ") used in the hydraulic model were estimated using field inspections at each cross section following the general guidelines described by Arcement, Jr. and Schneider (1989). Final adjustments to the values were made during the modelling of the reach. Channel " $n$ " values for the reach ranged from 0.049 to 0.057 , and overbank " $n$ " values ranged from 0.030 to 0.035 .

Dailey Hollow Branch drains into the North Branch Ottauquechee River approximately 185 feet downstream of this site. The close proximity of the confluence may affect the Dailey Hollow Branch hydraulics, especially if the flow peaks are simultaneous. However an analysis of potential backwater from the North Branch Ottauquechee River is outside of the scope of this study and normal depth at the exit section (EXITX) was assumed as the starting water surface. This depth was computed by use of the slope-conveyance method outlined in the User's manual for WSPRO (Shearman, 1990). The slope used was $0.0092 \mathrm{ft} / \mathrm{ft}$ which was determined from surveyed thalweg points downstream of the bridge.

The surveyed approach section (APTEM) was moved along the approach channel slope $(0.031 \mathrm{ft} / \mathrm{ft})$ to establish the modelled approach section (APPRO), one bridge length upstream of the upstream face as recommended by Shearman and others (1986). This approach also provides a consistent method for determining scour variables. 


\section{Bridge Hydraulics Summary}

$\begin{array}{lll}\text { Average bridge embankment elevation } & 100.3 \\ \text { Average low steel elevation } & 97.6 & f t\end{array}$

100-year discharge $\quad 2,170 \quad \mathrm{ft}^{3} / \mathrm{s}$

Water-surface elevation in bridge opening $\quad 88.8 \quad \boldsymbol{f t}$

Road overtopping? ___ N Discharge over road __ _ _ _. s

Area of flow in bridge opening $\quad 186 \quad \mathrm{ft}^{2}$

Average velocity in bridge opening $11.7 \mathrm{ft} / \mathrm{s}$

Maximum WSPRO tube velocity at bridge $\quad 14.5 \mathrm{ft} / \mathrm{s}$

Water-surface elevation at Approach section with bridge

91.2

Water-surface elevation at Approach section without bridge

89.9

Amount of backwater caused by bridge

$1.3-i$

500-year discharge $\quad 2,920 \quad \mathrm{ft}^{3} / \mathrm{s}$

Water-surface elevation in bridge opening

$89.6 f t$

Road overtopping? ___ N Discharge over road $-\ldots . / s$

Area of flow in bridge opening $\quad 219 \quad \mathrm{ft}^{2}$

Average velocity in bridge opening $\quad 13.3 \mathrm{ft} / \mathrm{s}$

Maximum WSPRO tube velocity at bridge 16.7_'s

Water-surface elevation at Approach section with bridge

92.7

Water-surface elevation at Approach section without bridge

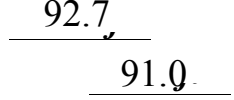

Amount of backwater caused by bridge

1.7 .

Incipient overtopping discharge ___ -- $\mathrm{ft}^{3} / \mathrm{s}$

Water-surface elevation in bridge opening $\quad--\quad t$

Area of flow in bridge opening

$-\boldsymbol{f t}^{2}$

Average velocity in bridge opening

Maximum WSPRO tube velocity at bridge $f t^{2}$

$-f^{-} \mathrm{ft} / \mathrm{s}$

Water-surface elevation at Approach section with bridge

Water-surface elevation at Approach section without bridge

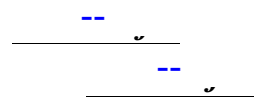
Amount of backwater caused by bridge

$-{ }_{-}^{-} \mathrm{t}$ 


\section{Scour Analysis Summary}

\section{Special Conditions or Assumptions Made in Scour Analysis}

Scour depths were computed using the general guidelines described in Hydraulic Engineering Circular 18 (Richardson and others, 1993). Scour depths were calculated assuming an infinite depth of erosive material and a homogeneous particle-size distribution. The results of the scour analysis are presented in tables 1 and 2 and a graph of the scour depths is presented in figure 8.

Contraction scour was computed by use of the clear-water contraction scour equation (Richardson and others, 1993, p. 35, equation 18). For contraction scour computations, the average depth in the contracted section (AREA/TOPWIDTH) is subtracted from the depth of flow computed by the scour equation (Y2) to determine the actual amount of scour.

Abutment scour was computed by use of the Froehlich equation (Richardson and others, 1993, p. 49, equation 24). The Froehlich equation gives "excessively conservative estimates of scour depths" (Richardson and others, 1993, p. 48). Variables for the Froehlich equation include the Froude number of the flow approaching the embankments, the length of the embankment blocking flow, and the depth of flow approaching the embankment less any roadway overtopping. 


\section{Scour Results}

$$
\text { 100-yr discharge 500-yr discharge }
$$

Contraction scour:

Main channel

Live-bed scour

Clear-water scour

Depth to armoring

Left overbank

Right overbank

Local scour:

Abutment scour

Left abutment

Right abutment

Pier scour

Pier 1

Pier 2

Pier 3
(Scour depths in feet)
Incipient
rtopping
harge

(Scour depths infeet)

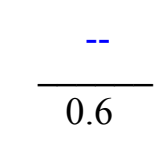

$18.5^{-}$

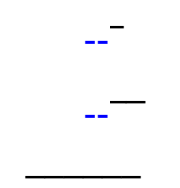

10.1

$6.7-$
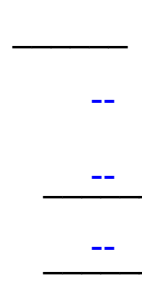

$\longrightarrow$

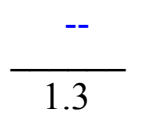

$26.0^{-}$

$--$
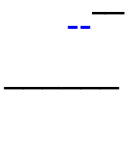

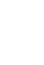




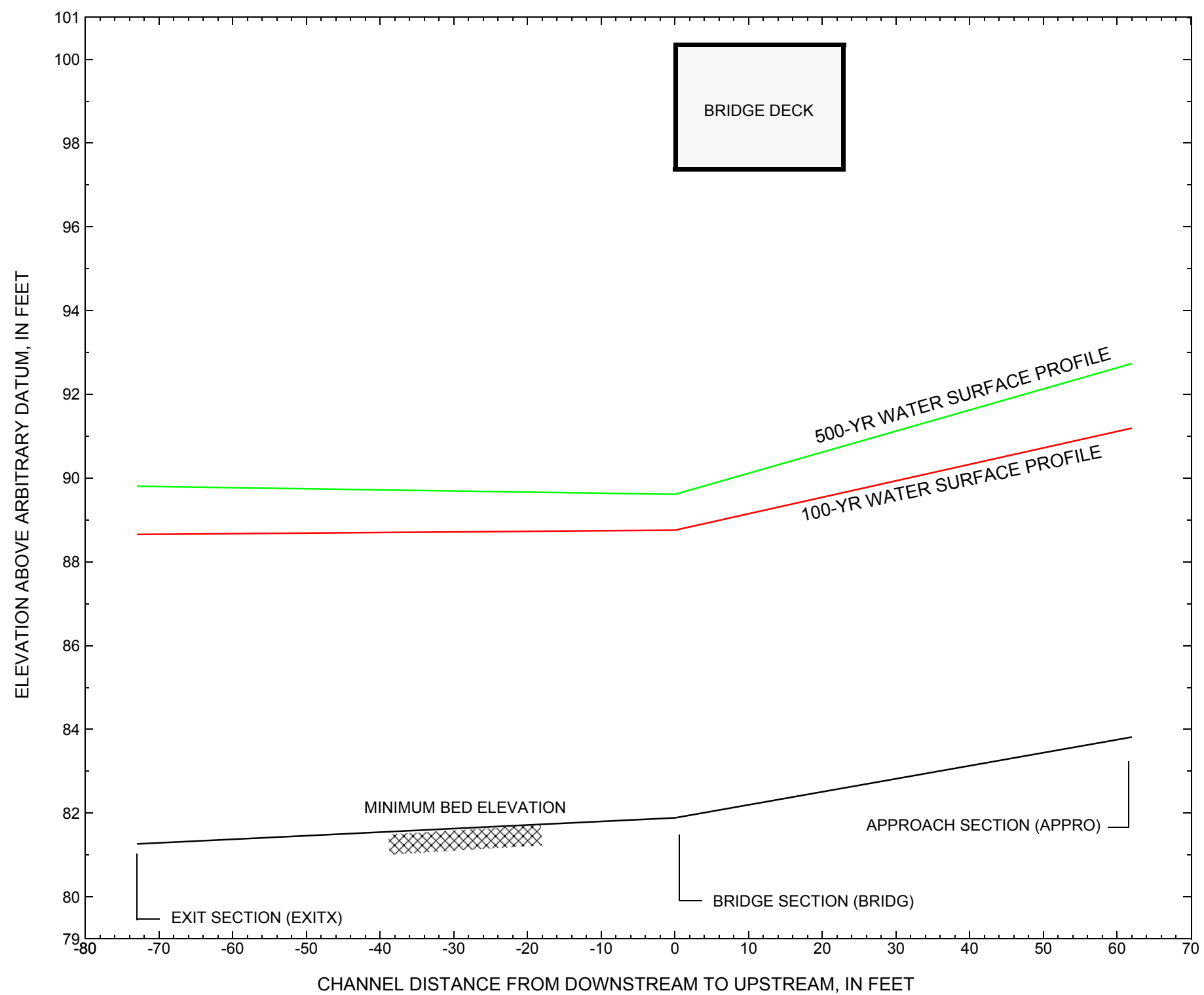

Figure 7. Water-surface profiles for the 100- and 500-yr discharges at structure BRIDTH00010003 on town highway 1, crossing Dailey Hollow Branch, Bridgewater, Vermont. 


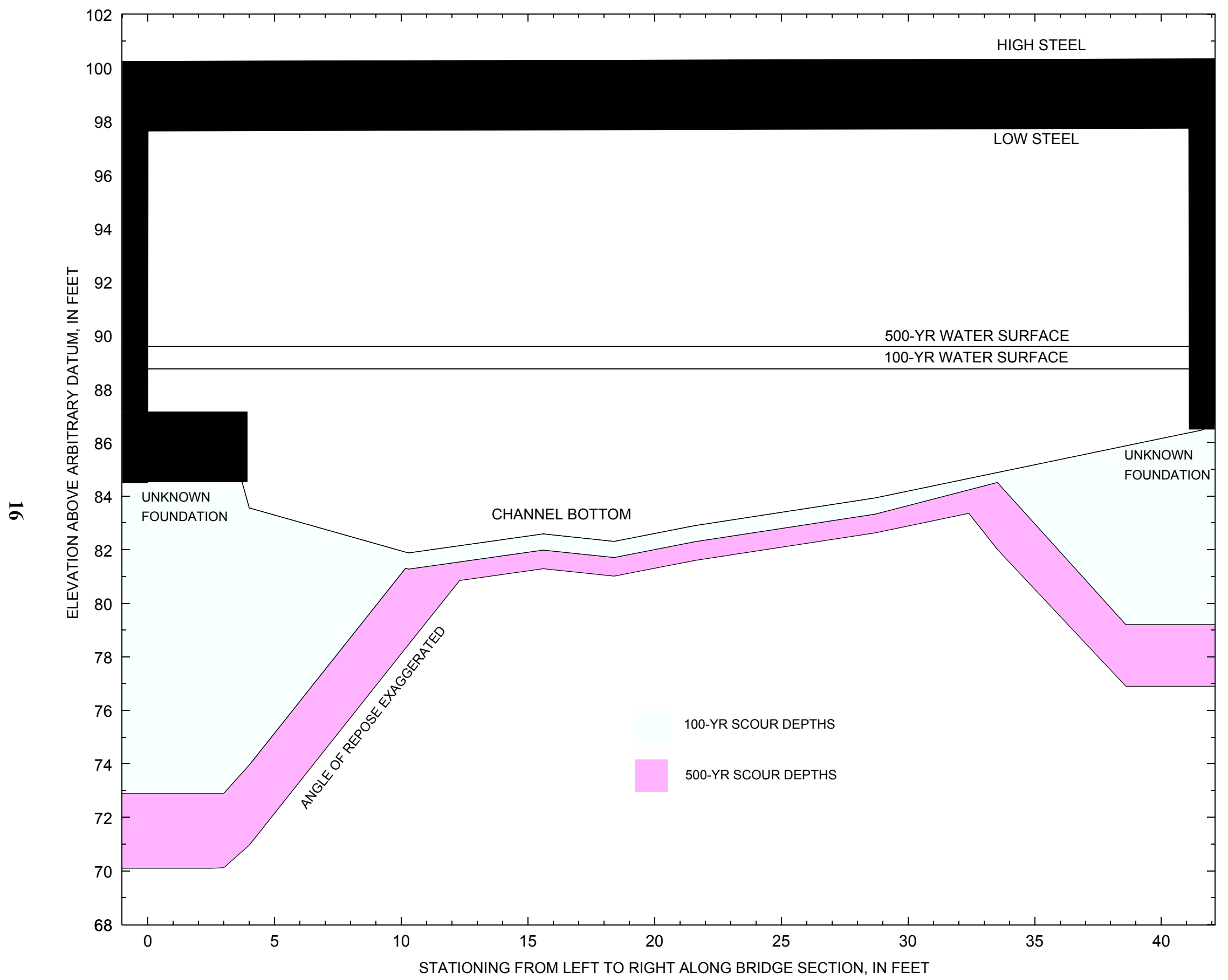

Figure 8. Scour elevations for the 100-yr and 500-yr discharges at structure BRIDTH00010003 on town highway 1, crossing Dailey Hollow Branch, Bridgewater, Vermont. 
Table 1. Remaining footing/pile depth at abutments for the 100-year discharge at structure BRIDTH00010003 on Town Highway 1, crossing Dailey Hollow Branch, Bridgewater, Vermont.

[VTAOT, Vermont Agency of Transportation; --,no data]

\begin{tabular}{|c|c|c|c|c|c|c|c|c|c|c|c|}
\hline Description & Station $^{1}$ & $\begin{array}{l}\text { VTAOT } \\
\text { minimum } \\
\text { low-chord } \\
\text { elevation } \\
\text { (feet) }\end{array}$ & $\begin{array}{l}\text { Surveyed } \\
\text { minimum } \\
\text { low-chord } \\
\text { elevation }{ }^{2} \\
\text { (feet) }\end{array}$ & $\begin{array}{l}\text { Bottom of } \\
\text { footing } \\
\text { elevation }{ }^{2} \\
\text { (feet) }\end{array}$ & $\begin{array}{c}\text { Channel } \\
\text { elevation at } \\
\text { abutment/ } \\
\text { pier }^{2} \\
\text { (feet) }\end{array}$ & $\begin{array}{l}\text { Contraction } \\
\text { scour depth } \\
\text { (feet) }\end{array}$ & $\begin{array}{l}\text { Abutment } \\
\text { scour } \\
\text { depth } \\
\text { (feet) }\end{array}$ & $\begin{array}{l}\text { Pier } \\
\text { scour } \\
\text { depth } \\
\text { (feet) }\end{array}$ & $\begin{array}{l}\text { Depth of } \\
\text { total scour } \\
\text { (feet) }\end{array}$ & $\begin{array}{c}\text { Elevation of } \\
\text { scour }^{2} \\
\text { (feet) }\end{array}$ & $\begin{array}{c}\text { Remaining } \\
\text { footing/pile } \\
\text { depth } \\
\text { (feet) }\end{array}$ \\
\hline \multicolumn{12}{|c|}{100 -yr. discharge is 2,170 cubic-feet per second } \\
\hline Left abutment & 0.0 & -- & 97.64 & -- & 83.6 & 0.6 & 10.1 & -- & 10.7 & 72.9 & -- \\
\hline Right abutment & 41.1 & -- & 97.66 & -- & 86.5 & 0.6 & 6.7 & -- & 7.3 & 79.2 & -- \\
\hline
\end{tabular}

1. Measured along the face of the most constricting side of the bridge.

2. Arbitrary datum for this study.

Table 2. Remaining footing/pile depth at abutments for the 500-year discharge at structure BRIDTH00010003 on Town Highway 1, crossing Dailey Hollow Branch, Bridgewater, Vermont.

[VTAOT, Vermont Agency of Transportation; --, no data]

\begin{tabular}{|c|c|c|c|c|c|c|c|c|c|c|c|}
\hline Description & Station $^{1}$ & $\begin{array}{l}\text { VTAOT } \\
\text { minimum } \\
\text { low-chord } \\
\text { elevation } \\
\text { (feet) }\end{array}$ & $\begin{array}{l}\text { Surveyed } \\
\text { minimum } \\
\text { low-chord } \\
\text { elevation } \\
\text { (feet) }\end{array}$ & $\begin{array}{l}\text { Bottom of } \\
\text { footing } \\
\text { elevation } \\
\text { (feet) }\end{array}$ & $\begin{array}{c}\text { Channel } \\
\text { elevation at } \\
\text { abutment/ } \\
\text { pier }^{2} \\
\text { (feet) }\end{array}$ & $\begin{array}{l}\text { Contraction } \\
\text { scour depth } \\
\text { (feet) }\end{array}$ & $\begin{array}{l}\text { Abutment } \\
\text { scour } \\
\text { depth } \\
\text { (feet) }\end{array}$ & $\begin{array}{l}\text { Pier } \\
\text { scour } \\
\text { depth } \\
\text { (feet) }\end{array}$ & $\begin{array}{l}\text { Depth of } \\
\text { total scour } \\
\text { (feet) }\end{array}$ & $\begin{array}{c}\text { Elevation of } \\
\text { scour }^{2} \\
\text { (feet) }\end{array}$ & $\begin{array}{c}\text { Remaining } \\
\text { footing/pile } \\
\text { depth } \\
\text { (feet) }\end{array}$ \\
\hline \multicolumn{12}{|c|}{500 -yr. discharge is 2,920 cubic-feet per second } \\
\hline Left abutment & 0.0 & -- & 97.64 & -- & 83.6 & 1.3 & 12.2 & -- & 13.5 & 70.1 & -- \\
\hline Right abutment & 41.1 & -- & 97.66 & -- & 86.5 & 1.3 & 8.3 & -- & 9.6 & 76.9 & -- \\
\hline
\end{tabular}

1. Measured along the face of the most constricting side of the bridge.

2. Arbitrary datum for this study. 


\section{SELECTED REFERENCES}

Arcement, G.J., Jr., and Schneider, V.R., 1989, Guide for selecting Manning's roughness coefficients for natural channels and flood plains: U.S. Geological Survey Water-Supply Paper 2339, 38 p.

Barnes, H.H., Jr., 1967, Roughness characteristics of natural channels: U.S. Geological Survey Water-Supply Paper 1849, 213 p.

Brown, S.A. and Clyde, E.S., 1989, Design of riprap revetment: Federal Highway Administration Hydraulic Engineering Circular No. 11, Publication FHWA-IP-89-016, 156 p.

Federal Highway Administration, 1983, Runoff estimates for small watersheds and development of sound design: Federal Highway Administration Report FHWA-RD-77-158

Froehlich, D.C., 1989, Local scour at bridge abutments in Ports, M.A., ed., Hydraulic Engineering--Proceedings of the 1989 National Conference on Hydraulic Engineering: New York, American Society of Civil Engineers, p. 13-18.

Hayes, D.C.,1993, Site selection and collection of bridge-scour data in Delaware, Maryland, and Virginia: U.S. Geological Survey WaterResources Investigation Report 93-4017, 23 p.

Interagency Advisory Committee on Water Data, 1982, Guidelines for determining flood flow frequency: U.S. Geological Survey, Bulletin 17B of the Hydrology Subcommittee, 190 p.

Johnson, C.G. and Tasker, G.D.,1974, Progress report on flood magnitude and frequency of Vermont streams: U.S. Geological Survey Open-File Report 74-130, 37 p.

Lagasse, P.F., Schall, J.D., Johnson, F., Richardson, E.V., Richardson, J.R., Chang, F., 1991, Stream Stability at Highway Structures: Federal Highway Administration Hydraulic Engineering Circular No. 20, Publication FHWA-IP-90-014, 195 p.

Laursen, E.M., 1960, Scour at bridge crossings: Journal of the Hydraulics Division, American Society of Civil Engineers, v. 86, no. HY2, p. 39-53.

Potter, W. D., 1957a, Peak rates of runoff in the Adirondack, White Mountains, and Maine woods area, Bureau of Public Roads

Potter, W. D., 1957b, Peak rates of runoff in the New England Hill and Lowland area, Bureau of Public Roads

Richardson, E.V., Harrison, L.J., Richardson, J.R., and Davis, S.R., 1993, Evaluating scour at bridges: Federal Highway Administration Hydraulic Engineering Circular No. 18, Publication FHWA-IP-90-017, 131 p.

Richardson, E.V., Simons, D.B., and Julien, P.Y., 1990, Highways in the river environment: Federal Highway Administration Publication FHWA-HI-90-016.

Ritter, D.F., 1984, Process Geomorphology: W.C. Brown Co., Debuque, Iowa, 603 p.

Shearman, J.O., 1990, User's manual for WSPRO--a computer model for water surface profile computations: Federal Highway Administration Publication FHWA-IP-89-027, 187 p.

Shearman, J.O., Kirby, W.H., Schneider, V.R., and Flippo, H.N., 1986, Bridge waterways analysis model; research report: Federal Highway Administration Publication FHWA-RD-86-108, 112 p.

Talbot, A.N., 1887, The determination of water-way for bridges and culverts.

U.S. Department of Transportation, 1993, Stream stability and scour at highway bridges, Participant Workbook: Federal Highway Administration Publication FHWA HI-91-011.

U.S. Geological Survey, 1966, Plymouth, Vermont 7.5 Minute Series quadrangle map: U.S. Geological Survey Topographic Maps, Photoinspected 1983, Scale 1:24,000. 


\section{APPENDIX A: \\ WSPRO INPUT FILE}




\section{WSPRO INPUT FILE}

GR

GR

GR

GR

$\mathrm{N}$

SA

XS

*

$\mathrm{BR}$

GR

GR

GR

GR

$\mathrm{N}$

CD

*

$\mathrm{XR}$

GR

GR

GR

GR

BP

*

$\mathrm{XT}$

GR

GR

GR

GR

GR

AS

GT

$\mathrm{N}$

SA

BP

*

HP 1 BRIDG

HP 2 BRIDG

HP 1 APPRO

HP 2 APPRO
U.S. GEOLOGICAL SURVEY WSPRO INPUT FILE bridO03.wsp CREATED ON 26-APR-95 FOR BRIDGE BRIDTH00010003 USING FILE brid003.dca Dailey Hollow Branch, Town Highway 1, Town of Bridgewater

$\begin{array}{lllllllllllllllllllll}6 & 29 & 30 & 552 & 553 & 551 & 5 & 16 & 17 & 13 & 3 & * & 15 & 14 & 23 & 21 & 11 & 12 & 4 & 7 & 3\end{array}$

21702920

0.00920 .0092

$\operatorname{EXITX} \quad-73$

\begin{tabular}{|c|c|c|c|c|c|c|c|}
\hline-119.9, & 92.44 & -30.7 & 94.16 & -21.0 & 89.95 & -4.2 & 85.64 \\
\hline-3.6 & 83.31 & 0.0, & 82.31 & 5.3 & 81.33 & 9.5 & 81.92 \\
\hline 16.6 & 81.26 & 22.4, & 82.25 & 32.6 & 82.89 & 38.9, & 86.93 \\
\hline 52.2 , & 96.88 & 176.4 , & 96.82 & & & & \\
\hline 0.035 & & 52 & 0.035 & & & & \\
\hline
\end{tabular}

FULLV 0 * * * 0.009

BRIDG $0 \quad 97.65 \quad 20$

\begin{tabular}{|c|c|c|c|c|c|c|c|}
\hline 0.0, & 97.64 & 0.6 , & 87.00 & 3.8, & 87.00 & 4.0, & 83.56 \\
\hline 6.5, & 82.87 & 10.3 & 81.88 & 15.6 & 82.59 & 18.4 & 82.31 \\
\hline 21.6, & 82.90 & 28.7 & 83.93 & 41.1 , & 86.47 & 41.1 & 97.66 \\
\hline
\end{tabular}

0.049

$136.5 * \star 62.57 .2$

$\begin{array}{llll}\text { RDWAY } & 11 & 21.7 \quad 1\end{array}$

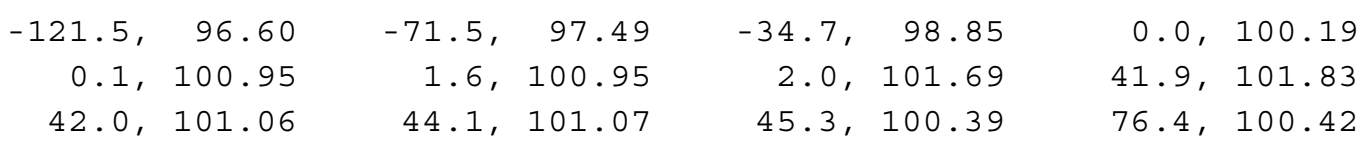

0

APTEM 108

$$
-102.5,105.83
$$

$-72.0,104.05$

$-7.4, \quad 89.75$

$-5.7,88.71$

$13.2, \quad 85.24$

$20.9, \quad 85.71$

$38.7,90.29$

$42.8,91.99$

$96.3,109.49$

APPRO

62

$-1.43$

0.030

$-19.4$

0.057

57.3

0
$-57.4, \quad 98.61$

$2.1, \quad 87.12$

$26.8, \quad 86.21$

$57.3, \quad 99.83$

0.030
$-19.4,98.11$

$5.0, \quad 85.74$

$37.1, \quad 88.72$

$83.5,101.43$ 


\section{APPENDIX B: \\ WSPRO OUTPUT FILE}




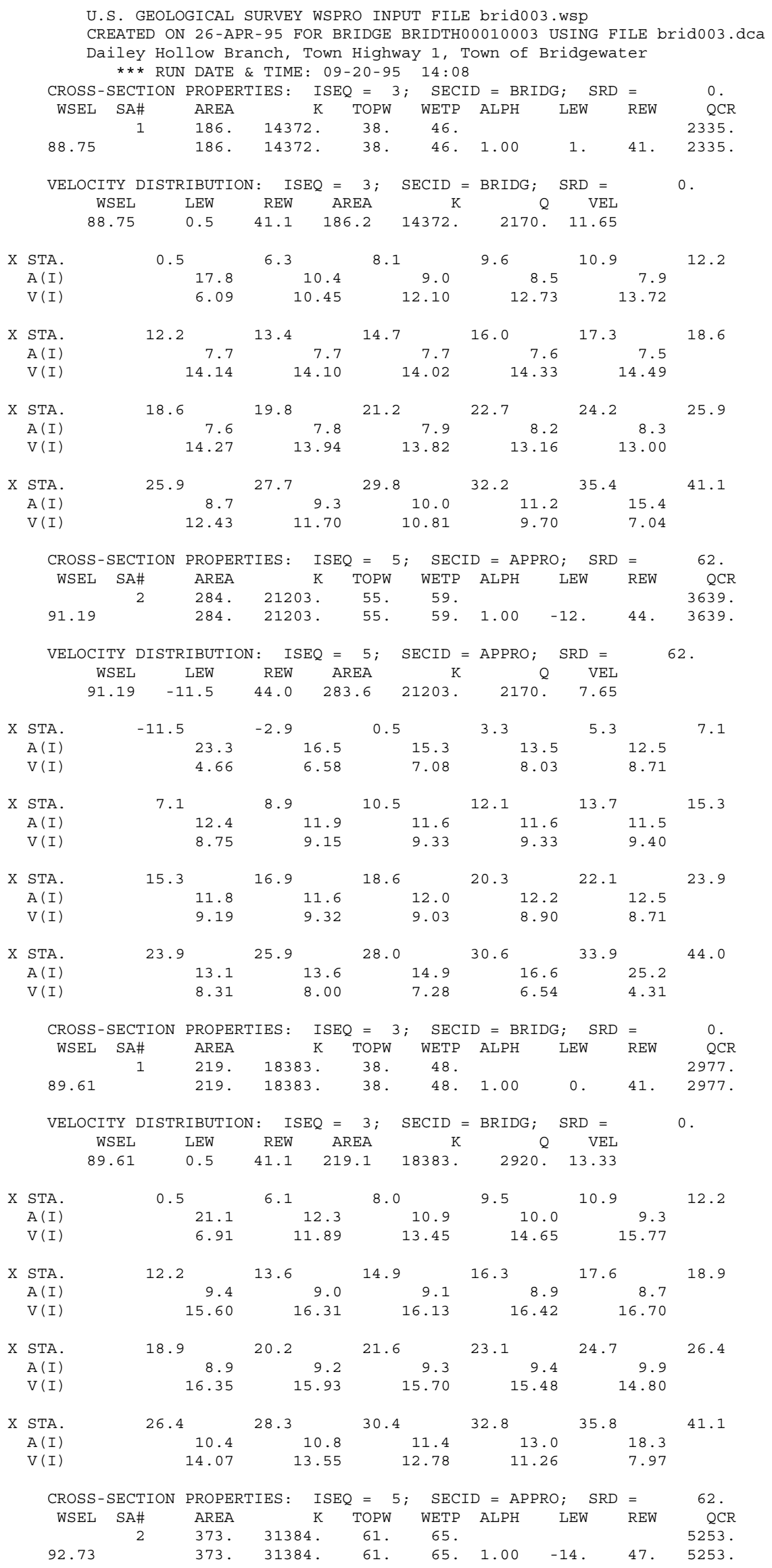


WSPRO OUTPUT FILE (continued)

\begin{tabular}{|c|c|c|c|c|c|c|c|c|c|c|c|}
\hline & $\mathrm{VE}$ & $\begin{array}{l}\text { CITY I } \\
\text { WSEL } \\
92.73\end{array}$ & $\begin{array}{c}\text { DISTRIBUTIC } \\
\text { LEW } \\
-13.7\end{array}$ & $\begin{array}{l}\text { N : I } \\
\text { REW } \\
46.8\end{array}$ & $\begin{array}{r}\mathrm{SEQ}= \\
\mathrm{AR} \\
373\end{array}$ & $\begin{array}{l}5 ; \\
.0\end{array}$ & $\begin{array}{r}\text { SECID } \\
\text { K } \\
31384 .\end{array}$ & $\begin{array}{r}=\text { APPRO } \\
2920 .\end{array}$ & $\begin{array}{l}\mathrm{RD}= \\
\mathrm{VEL} \\
7.83\end{array}$ & & 2 . \\
\hline$x$ & STA. & & -13.7 & -4.1 & & -0.6 & & 2.3 & 4.7 & & 6.6 \\
\hline & $A(I)$ & & 31.6 & & 21.5 & & 19.5 & 18.1 & & 16.3 & \\
\hline & $V(I)$ & & 4.62 & & 6.79 & & 7.49 & 8.05 & & 8.95 & \\
\hline & STA. & & 6.6 & 8.5 & & 10.3 & & 12.0 & 13.7 & & 15.4 \\
\hline & $A(I)$ & & 15.9 & & 15.6 & & 15.3 & 15.2 & & 15.1 & \\
\hline & $V(I)$ & & 9.16 & & 9.37 & & 9.57 & 9.58 & & 9.64 & \\
\hline$X$ & STA. & & 15.4 & 17.2 & & 18.9 & & 20.8 & 22.7 & & 24.7 \\
\hline & $A(I)$ & & 15.4 & & 15.2 & & 15.7 & 15.7 & & 16.7 & \\
\hline & $\mathrm{V}(\mathrm{I})$ & & 9.47 & & 9.59 & & 9.27 & 9.32 & & 8.76 & \\
\hline & STA. & & 24.7 & 26.8 & & 29.1 & & 31.9 & 35.5 & & 46.8 \\
\hline & $A(I)$ & & 16.8 & & 18.1 & & 19.5 & 22.6 & & 33.0 & \\
\hline & $V(I)$ & & 8.70 & & 8.07 & & 7.48 & 6.45 & & 4.42 & \\
\hline
\end{tabular}

U.S. GEOLOGICAL SURVEY WSPRO INPUT FILE bridO03.wsp

CREATED ON 26-APR-95 FOR BRIDGE BRIDTH00010003 USING FILE brid003.dca Dailey Hollow Branch, Town Highway 1, Town of Bridgewater

*** RUN DATE \& TIME: 09-20-95 14:08

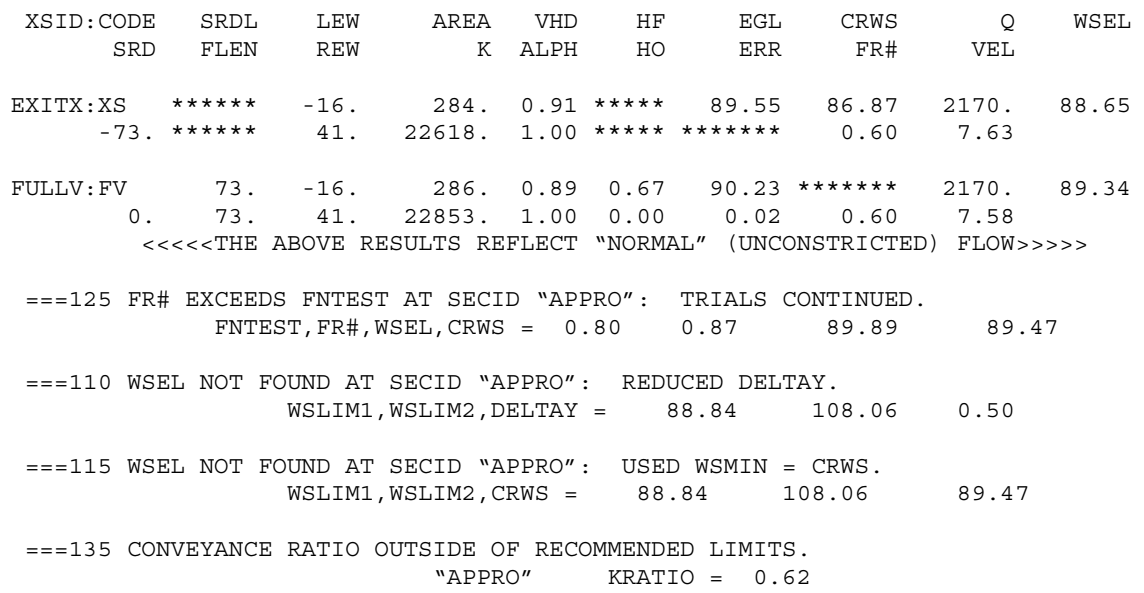

\begin{tabular}{|c|c|c|c|c|c|c|c|c|}
\hline XSID : CODE & SRD & LEW & REW & $\mathrm{Q}$ & $\mathrm{K}$ & AREA & VEL & WSEI \\
\hline EXITX:XS & -73 & -16 & 41. & 2170 . & 22618 . & 284 . & 7.63 & 88.65 \\
\hline FULLV : FV & 0 & -16 & 41. & 2170 . & 22853 . & 286. & 7.58 & 89.34 \\
\hline BRIDG : BR & 0 & 1. & 41. & 2170. & 14364 . & 186. & 11.66 & 88.75 \\
\hline RDWAY : RG & \multicolumn{3}{|c|}{ 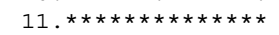 } & \multicolumn{3}{|c|}{ 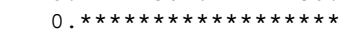 } & \multicolumn{2}{|c|}{ 1. $00 * \star \star * \star * \star * *$} \\
\hline APPRO:AS & 62. & -12 & 44. & 2170 . & 21186 & 283. & 7.66 & 91.19 \\
\hline XSID : CODE & XLKQ & XRKQ & & & & & & \\
\hline APPRO : AS & -3 & 38 & 2164 & & & & & \\
\hline
\end{tabular}


WSPRO OUTPUT FILE (continued)

$\begin{array}{crrrrrrrrr}\text { SECOND USER DEFINED } & \text { TABLE. } & & & & & & \\ \text { XSID:CODE } & \text { CRWS } & \text { FR\# } & \text { YMIN } & \text { YMAX } & \text { HF } & \text { HO } & \text { VHD } & \text { EGL } & \text { WSEL } \\ \text { EXITX:XS } & 86.87 & 0.60 & 81.26 & 96.88 * * * * * * * * * * & 0.91 & 89.55 & 88.65 \\ \text { FULLV:FV } & * * * * * * * * & 0.60 & 81.92 & 97.54 & 0.67 & 0.00 & 0.89 & 90.23 & 89.34 \\ \text { BRIDG: BR } & 88.51 & 0.93 & 81.88 & 97.66 & 1.06 & 0.25 & 2.11 & 90.86 & 88.75 \\ \text { RDWAY : RG } & * * * * * * * * * * * * * * * & 96.60 & 110.88 * * * * * * * * * * * * * * * * * * * * * * * * * * * * * \\ \text { APPRO:AS } & 89.47 & 0.60 & 83.81 & 108.06 & 0.41 & 0.83 & 0.91 & 92.10 & 91.19\end{array}$

U.S. GEOLOGICAL SURVEY WSPRO INPUT FILE brid003.wsp

CREATED ON 26-APR-95 FOR BRIDGE BRIDTH00010003 USING FILE brid003.dca

Dailey Hollow Branch, Town Highway 1, Town of Bridgewater

*** RUN DATE \& TIME: 09-20-95 14:08

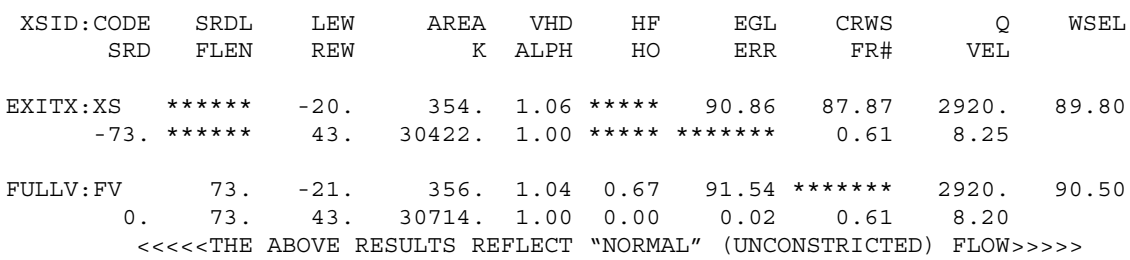

$==125$ FR\# EXCEEDS FNTEST AT SECID "APPRO": TRIALS CONTINUED.

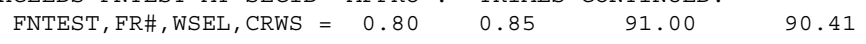

$===110$ WSEL NOT FOUND AT SECID "APPRO": REDUCED DELTAY.

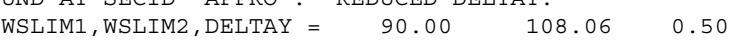

$==115$ WSEL NOT FOUND AT SECID "APPRO": USED WSMIN = CRWS

$$
\text { WSLIM1, WSLIM2, CRWS }=\begin{array}{ccc}
90.00 & 108.06 & 90.41
\end{array}
$$

$===135$ CONVEYANCE RATIO OUTSIDE OF RECOMMENDED LIMITS

$$
\text { "APPRO" KRATIO }=0.65
$$

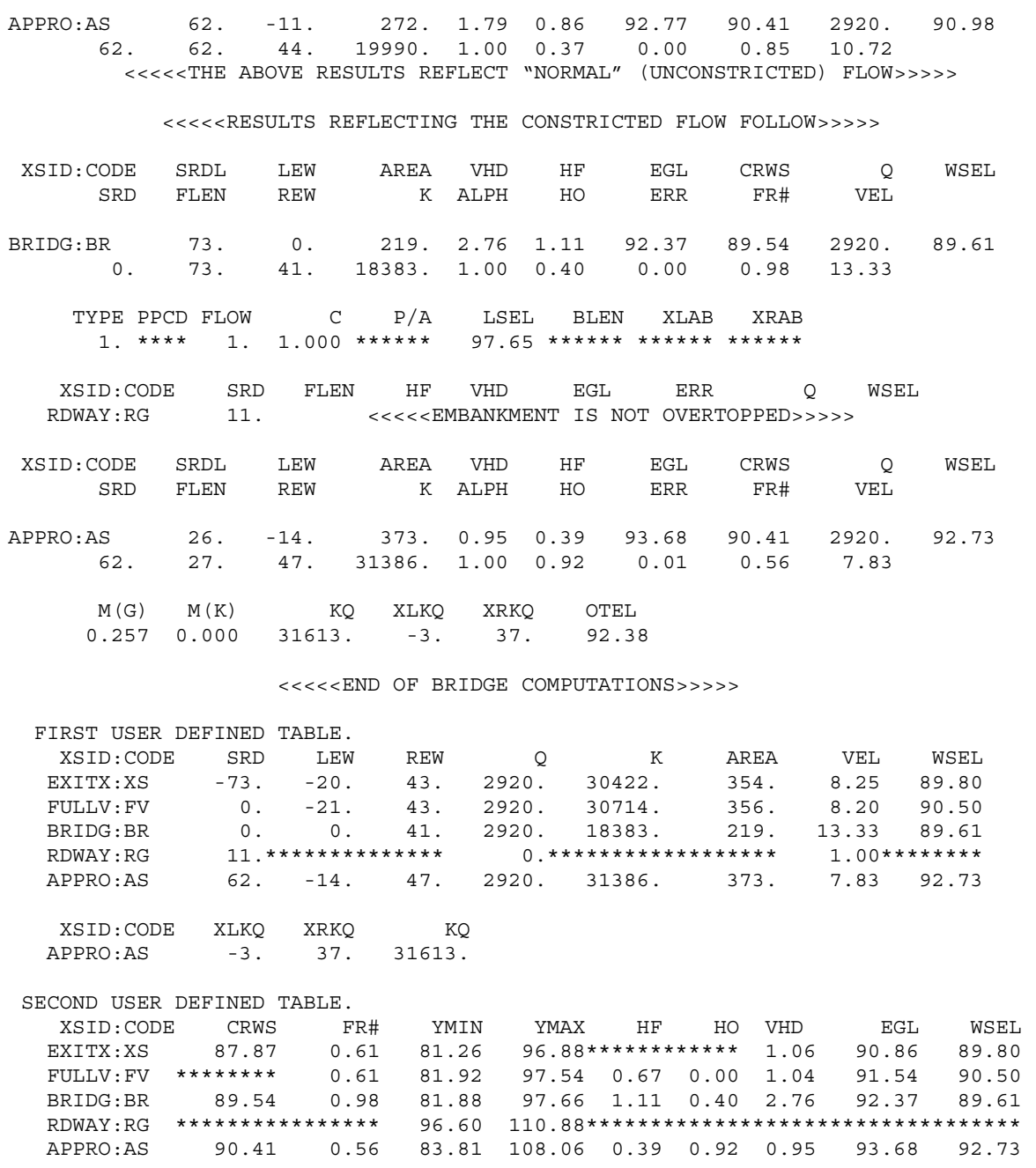




\section{APPENDIX C:}

\section{BED-MATERIAL PARTICAL-SIZE DISTRIBUTION}




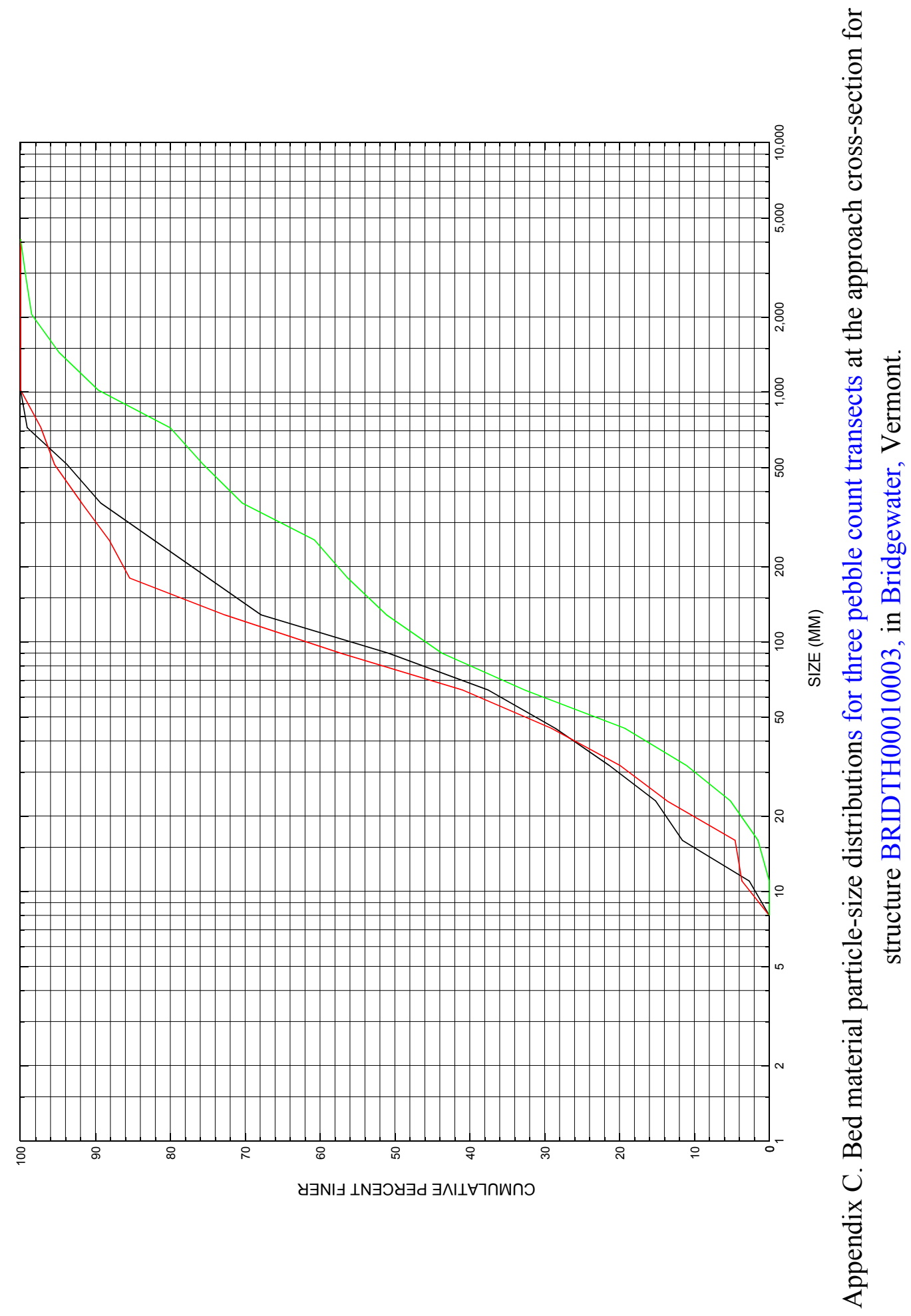




\section{APPENDIX D: \\ HISTORICAL DATA FORM}

